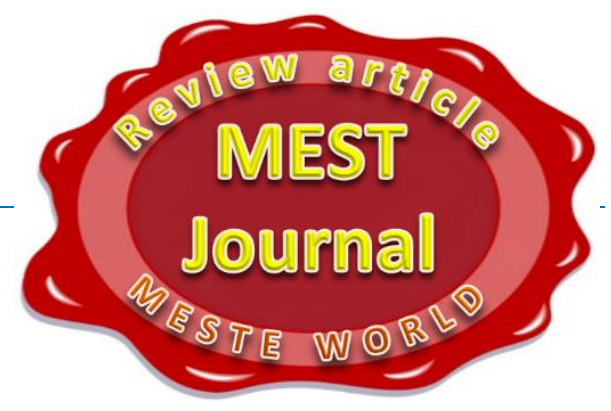

\title{
CONSTRUCTION OF RAILWAY TRANSPORT CORRIDORS IN BULGARIA BY PROMOTING PUBLIC-PRIVATE PARTNERSHIP
}

\author{
Petya Koralova \\ “Todor Kableshkov" University of Transport, Sofia, Bulgaria
}

CMESTE

JEL Category: L92, O18, R4

\begin{abstract}
:
One of the main problems that hinder the development of railway transport in countries such as Bulgaria is the lack of fully liberalized market. As a result of the review of the Trans-European Transport Network Corridors in 2014, most of the Bulgarian transport strategy documents for the period 2014-2020 are directed toward the funding of railway infrastructure investment projects to stimulate better quality, safety and security of the services provided. In this regard, the main objective of the work is to reveal the possibilities of promoting risk allocation between public and private partners in order to promote construction of railway transport corridors in Bulgaria. Methods of induction and deduction, as well as methods of analysis and synthesis, are applied for the purposes of the research. A brief review of the main infrastructure projects, concerning railway transport corridors in the country, is made. In the paper, special attention is paid to the widely used public-private partnership forms for the fulfillment of railway infrastructure projects. The ideas, presented in the work would be useful for countries that meet the same problems as Bulgaria in terms of attracting private investment initiatives so as to provide railway transport services with better quality.
\end{abstract}

Keywords: public-private partnership, railway transport, core network corridors

\section{INTRODUCTION}

Development of financial markets and the opportunities the European funding sources provide could be perceived as prerequisites for attracting private investment initiatives in terms of construction, maintenance, exploitation and management of the transport infrastructure. What is typical for the transport sector is that there is

The address of the author:

Petya Koralova

埄”pkoralova@vtu.bg enough potential for long-term growth. On the other hand, transport infrastructure is a long-term tangible asset that generates direct and indirect benefits for both the private sector and the society as a whole. In this regard, combining public funding with private initiatives must be seen not only as a form of partnership but also as a way to stimulate effective management and exploitation of the public infrastructure. That is why the Connecting Europe Facility was implemented in order to enable fulfillment of projects of public interest whose main goal is to develop, construct or upgrade the existing infrastructure in the Trans- 
European Transport Network. (EP, Regulation $1316 / 2013$ on the European Parliament and of the Council on establishing the Connecting Europe Facility, 2013)

Construction, maintenance, and rehabilitation of transport infrastructure is a laborious process that requires significant investments. This fact could also be confirmed by the forecasts of the European Commission for funding of the transport infrastructure till 2030. The total value of the funding is 1.5 trillion euros (Bodewig, 2014), 500 billions of which should be utilized for the construction of the TEN-T network. Having in mind the importance of the trans-European transport network for the economic and social growth of Europe, the Connecting Europe Facility reveals opportunities for combining funding initiatives between European Structural and Investment Funds, Horizons 2020 and European Neighbourhood Instrument. The application of such types of funding contributes to the emergence of partnerships between private and public partners whose main objective is to found working packages; clear division of duties and responsibilities among partners and risk allocation, regarding:

- Integrating railways in the multimodal transport services along TEN-T Network;

- Promoting innovations in the transport sector by usage of bio-fuels;

- Application of information and communication technologies in order to ensure effective utilization of the transport infrastructure;

- Integrating urban areas in the TEN-T network by providing safe and secure transport services.

The main objectives of the Connecting Europe Facility that cover the infrastructure of all transport modes are as follows:

- Remove bottlenecks that impede freight and passengers transport services;

- Increase interoperability in the railway transport; building up the missing links among the core network corridors and developing the cross-border connections;

- Ensure sustainable transport system by promoting low-carbon, innovative and energy efficient transport technologies;
- Optimize interoperability among transport modes by construction of logistic terminals

The Connecting Europe Facility consisted also a detailed description of the core network corridors that have to be constructed, rehabilitated and developed, as well as the total budget of the funding for the period 2014-2020 which is $33.2 \mathrm{bln}$. euros.

According to the aforementioned, the main objective of the research is to reveal the possibilities of promoting risk allocation between public and private partners in order to promote construction of railway transport corridors in Bulgaria. Bulgarian section of Orient/East-Med Core Network Corridor is the object of the analysis and its subject is the methods by which this goal could be achieved. The main hypothesis that the author proves as a result of the research is the following: there are real opportunities for the development of the railway network of Bulgaria as part of the TEN-T network by promoting the publicprivate partnership.

The limitations of the research are connected with the size of the study, which is a part of conference proceedings and the main problems that are outlined in the analysis could not be revealed in details.

\section{DEVELOPMENT OF THE TRANS- EUROPEAN TRANSPORT NETWORK}

The development of Trans-European Transport Network (TEN-T) is of great importance for the competitiveness of national transport systems of member states. The trans-European transport network consists of structure at two layers: comprehensive network which is a network that covers all the existing and planned transport infrastructure of TEN-T, as well as the measures for stimulating sustainable exploitation of this network from social and environmental point of view, and core network - consists of these sections of the comprehensive network that are of strategic importance for the development of the TEN-T (EP, Regulation 1315/2013 of the European Parliament and of the Council on Union guidelines for the development of the transEuropean transport network, 2013). The main 
objectives of the policy for building up the transEuropean transport network are as follows:

- Cohesion, based on better accessibility of the transport infrastructure, ensures better quality of the services provided and better connectivity of the sections included in the TEN - T network;

- Efficiency, based on removing bottlenecks and building up the missing links at border crossings as well as development of the interoperability among transport modes;

- Sustainability, based on reducing greenhouse gas emissions, promoting clean fuel usage in passenger and freight transportation and internalization of the external costs of transport;

- More benefits for the transport infrastructure users through better mobility of citizens in EU and third countries;

- Boosting safety and quality of transport services and provide better accessibility to the transport infrastructure for disabled people.

The core network corridors that are included in the TEN-T network are the following (DGMT, 2015):

The Scandinavian-Mediterranean Corridor - it links the major urban areas, ports and industrial centers of Finland, Sweden, Northern and Southern Germany, as well as the Alps and Italy;

The North Sea-Baltic Corridor - it passes through Finland, Estonia, Poland, Germany, Netherlands, and Belgium;

The North Sea - Mediterranean Corridor - it stretches from Ireland and north of the United Kingdom, through the Benelux and the south of France;

The Baltic-Adriatic Corridor - it passes through the industrial centers of southern Poland, Vienna, Bratislava, Eastern Alpine Region and north of Italy;

The Orient/East- Med Corridor - it connects the maritime ports of North, Baltic, Black and Mediterranean Seas;

The Rhine-Alpine Corridor - connects the ports of Rotterdam and Antwerp with the Mediterranean basin of Genoa via Switzerland;

The Atlantic Corridor - links the western part of Iberian Peninsula with the French ports Le Havre and Rouen;
The Rhine-Danube Corridor - passes through the main Rhine and Danube waterways and links the central regions of Danubian countries with Ukrainian border and Southern Germany;

The Mediterranean Corridor - connects the Hungarian-Ukrainian border with the Iberian Peninsula.

\section{RAIL TRANSPORT CORRIDORS PASSING THROUGH THE TERRITORY OF BULGARIA}

Orient/East-Med Core Network Corridor is of significant importance for the economic development of the country, as well as for the competitiveness of its transport system. The corridor passes through the territory of Bulgaria from north to south and from north to southeast.

In accordance with the Connecting Europe Facility, the pre-identified infrastructure projects that have to be funded cover the following sections of Orient/East-Med Core Network Corridor:

- Dresden - Praha - high-speed rail; freight bypass; rail-airport connection;

- Hamburg - Dresden - Praha - Pardubice ensure safe navigability in inland waterways;

- Prague - Brno - Breclav - construction and upgrading of multi-modal platform in Brno;

- Breclav - Hegyeshalom - upgrading of cross-border connections;

- Budapest - Arad - Timisoara - Calafat upgrading of the railway infrastructure network;

- Vidin - Sofia - Burgas - Turkish border studies and upgrading of the railway section Sofia - Burgas

- Sofia - Thessaloniki - Athens - Piraeus upgrading, and rehabilitation of the railway network in the section

- Vidin - Craiova - cross-border upgrading;

- Thessaloniki - Igoumenitsa - developing multi-modal connection and port upgrading;

- Athens - Lemesos - Lefkosia - Larnaka upgrading of the port infrastructure and application of information and communication technologies;

- Athens - Patra - studies and port interconnections 


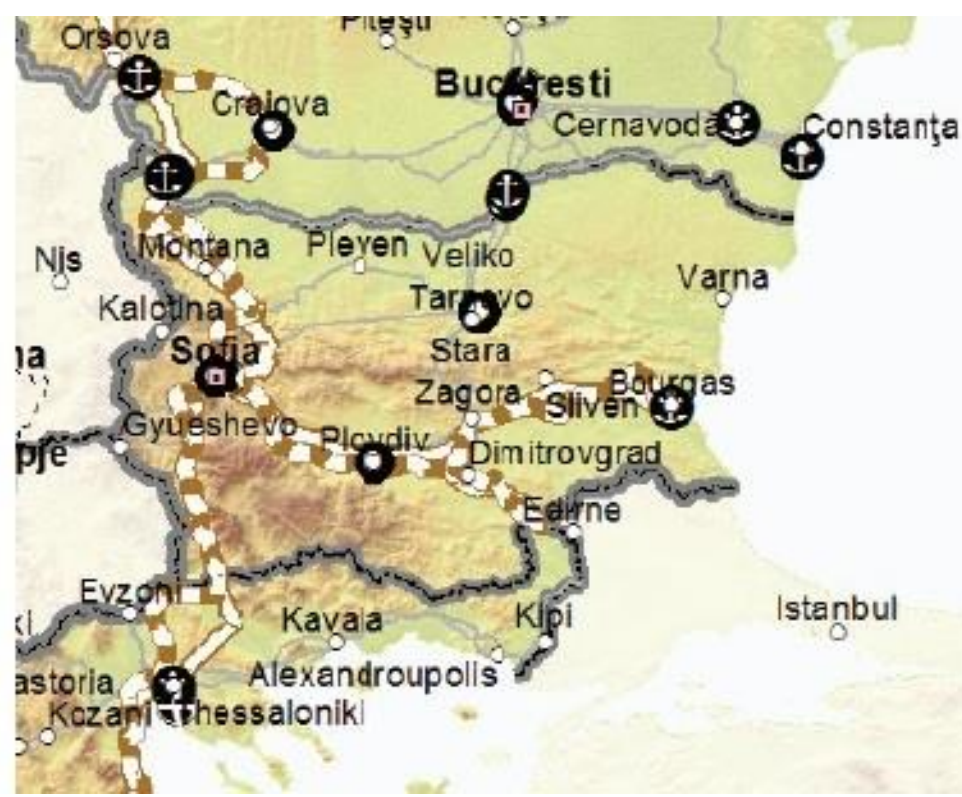

Figure 1 Scheme of the Bulgarian section of Orient/East-Med Core Network Corridor

Source: Directorate General for Mobility and Transport, 2015

Most of the transport connections among relevant member-states along the corridor are carried out by railway transport. The main objective in this regard is to construct a transport network that is low carbon, energy efficient and environmentally friendly, and to support better interoperability among railway, sea and inland waterway transport. This objective is easily achievable as most of the member-states along the corridor are well provided with the railway network. The density of the railway network in member-states along the corridor is approximately equal to the average values for EU-28 and even in some of the countries it is higher (see Table 1)

Table 1 Density of the railway network in member states along Orient/East-Med Core Network Corridor, $\mathrm{km} / 1000 \mathrm{sq}$ mi of the territory of the country

\begin{tabular}{|c|c|c|c|c|c|c|c|c|c|c|c|c|c|c|}
\hline \multirow{2}{*}{ Countries } & \multicolumn{10}{|c|}{ Years } \\
\cline { 2 - 15 } & 2000 & 2001 & 2002 & 2003 & 2004 & 2005 & 2006 & 2007 & 2008 & 2009 & 2010 & 2011 & 2012 & 2013 \\
\hline EU-28 & 50.35 & 49.64 & 49.73 & 49.99 & 49.35 & 49.10 & 49.16 & 49.23 & 49.31 & 49.33 & 49.35 & 49.52 & 49.41 & 49.14 \\
\hline BG & 38.92 & 38.92 & 38.90 & 38.88 & 38.37 & 37.42 & 3735 & 37.0 & 37.33 & 37.39 & 36.91 & 36.68 & 36.67 & 36.32 \\
\hline CZ & 119.74 & 120.5 & 121.72 & 121.75 & 121.87 & 121.90 & 121.68 & 121.57 & 120.28 & 120.16 & 120.05 & 120.07 & 120.06 & 119.93 \\
\hline DE & 102.46 & 100.77 & 100.29 & 100.96 & 97.26 & 95.83 & 95.55 & 94.90 & 94.80 & 94.41 & 94.39 & 94.02 & 93.84 & 93.66 \\
\hline GR & 18.07 & 18.01 & 18.06 & 18.29 & 18.56 & 19.52 & 19.01 & 19.33 & 19.34 & 19.34 & 19.34 & 19.35 & 19.35 & 17.16 \\
\hline HU & 86.05 & 83.16 & 85.45 & 85.46 & 85.46 & 85.46 & 86.56 & 85.37 & 84.83 & 84.83 & 84.84 & 84.98 & 84.67 & 84.90 \\
\hline AT & 67.54 & 67.92 & 68.90 & 68.99 & 67.66 & 67.85 & 69.36 & 69.36 & 67.53 & 63,85 & 60.07 & 59.86 & 58.35 & 58.35 \\
\hline RO & 46.21 & 46.21 & 46.15 & 46.47 & 46.37 & 45.92 & 45.22 & 45.21 & 45.21 & 45.20 & 45.21 & 45.21 & 45.21 & 45.17 \\
\hline SK & 74.68 & 74.68 & 74.58 & 74.58 & 74.64 & 74.60 & 74.60 & 74.01 & 73.89 & 73.89 & 73.87 & 73.91 & 74.05 & 74.05 \\
\hline
\end{tabular}

Source: Directorate General for Mobility and Transport, 2015

Czech Republic (Directorate General for Mobility and Transport, 2015) is one of the well-provided countries with railway network $-120 \mathrm{~km}$ rail tracks of $1000 \mathrm{sq}$ mi of its territory. The Higher density of the railway network is also observed in Germany, Hungary, Slovak Republic and Romania. Bulgaria
(37.7 km of $1000 \mathrm{sq} \mathrm{mi}$ of the territory) ranks next to the last among the countries - Greece $(18.8 \mathrm{~km}$ of $1000 \mathrm{sq}$ mi of the territory) but compared to EU28 its density of the railway network gets closer to the average values. Consequently, the existing railway network in the reviewed member states is 
enough for carrying out passenger and freight transportation. This conclusion could be confirmed by the increasing number of infrastructure projects, funded by the Connecting Europe Facility. The objective of the most of the projects is modernization, rehabilitation and application of information and communication technologies in railway transport network but not the construction of new railway tracks. The same process is applicable in Bulgaria.

The railway infrastructure along Orient/East-Med Corridor comprises high-speed and conventional rail lines (EP, Regulation 1315/2013 of the European Parliament and of the Council on Union guidelines for the development of the transEuropean transport network, 2013), terminals, logistic platforms, railway stations and telematic applications. The railway lines for conventional transport are classified as lines for movement of trains with speed over $250 \mathrm{~km} / \mathrm{h}$, conventional lines for movement of rolling stock with speed above $250 \mathrm{~km} / \mathrm{h}$ and specifically equipped lines for movement of rolling stock in heavy terrains.

The main objectives of the TEN-T network transport policy are oriented toward implementation of the European Railway Traffic Management System (ERTMS); unification of the track gauge; mitigation of noise and vibration, caused by railways; interoperability among inland waterway, road, and railway transport; better safety and security at railway crossings.

\section{TYPES OF PUBLIC-PRIVATE} PARTNERSHIPS THAT ARE COMMON FOR FULFILLMENT OF RAILWAY INFRASTRUCTURE PROJECTS

The very common way of investment for rehabilitation of transport infrastructure in the last years is allocating financial risk among public and private companies in order to fully liberalize and enhance the competitiveness of stakeholders at the transport market and provide transportation services with better quality.

A public-private partnership (PPP) is a partnership between the public and private sector for the purpose of delivering a project or a service traditionally provided by the public (DGRP, 2003). PPPs recognize that both parties have certain advantages relative to the other in the performance of specific tasks. Widely used PPP forms for the fulfillment of railway transport infrastructure projects are as follows (Gechev et al, 2015):

Design-Bid-Build - this form of partnership allows the most appropriate and competitive partner to be chosen for the fulfillment of the construction phase of the investment project in order to provide better transportation services.

Build-Operate-Transfer - according to this type of PPP, the financial risk is allocated between partners, as the public partner is responsible for the funding of infrastructure, while the private partner must carry out the construction and exploitation phase of the infrastructure. This results in total cost optimization and brings social and economic benefits for the society.

Concession - this one is not a typical form of PPP and is applicable for investment projects when no public funding is needed. In this regard, the PPP premium for the private partner corresponds with higher total costs and obligation for the provision of public services.

\section{REVIEW OF THE INFRASTRUCTURE PROJECTS FOR CONSTRUCTION OF RAILWAY TRANSPORT CORRIDORS IN BULGARIA}

The overall state of rail infrastructure in Bulgaria is unsatisfactory, no matter that the density of the rail network is close to the average values for the EU28 (see Table 1) and approximately $70 \%$ of the rail lines are electrified which equals to the European average level of electrification of the railway network. These dues to the fact that most of the railway infrastructure was constructed 50 years ago (MTITC, 2014) which makes it inappropriate for high-speed and conventional passenger and freight transportation services. Such lines also exist at the Bulgarian section of the Orient/East-Med Corridor, namely in the direction Sofia - Plovdiv (railway section Sofia Septemvri); Vidin - Sofia (railway section Vidin Medkovets); Plovdiv - Burgas (railway section Plovdiv - Mihailovo). For the railway network of the country are also typical poor interconnections with the port and airport infrastructure, as well as 
the lack of fully applied information and communication technologies for train and traffic management.

To overcome the existing problems that hinder the development of the railway transport in Bulgaria, the Ministry of transport, information technologies, and communications adopted a new Operational Programme Transport and Transport Infrastructure for the horizon 2014-2020. The main objective of the program is to fund infrastructure projects of national and European significance. One of the important projects to be fulfilled is the construction of railway tracks along the TEN-T network. According to this priority axis, the purpose of most of the funding is directed toward continuing rehabilitation of the conventional railway tracks, as well as the application of information and communication technologies in the section Sofia - Burgas. Most of the priority projects in this regard concern rehabilitation of the railway line Plovdiv - Burgas; implementation of interlocking systems in the railway section Karnobat - Burgas; development of railway junctions Plovdiv and Burgas; modernization of the rail lines Plovdiv - Orizovo; Orizovo Mihailovo and Yambol - Zimnitsa. Special attention is paid to the equipment of $293 \mathrm{~km}$ of the rail network between Plovdiv and Burgas with communication technologies, as well as to the construction of double electrified railway lines in the section Elin Pelin - Intiman - Septemvri. The expected benefits as a result of the fulfillment of the projects are related to better reliability, safety, and security of the railway network in the country as well as the higher capacity of the infrastructure for passenger and freight transport services between Sofia and the Black Sea.

Another infrastructure project which is a section of the Orient/East-Med Core Network Corridor along the territory of the country is the modernization and full electrification of the railway section Plovdiv - Svilengrad. Most of the activities that have to be carried out concern electrification of the railway section Parvomay - Svilengrad, and modernization of the rail line Svilengrad - Turkish border.

Operational Programme "Transport and transport infrastructure" 2014-2020 presents possibilities for funding investment projects concerning rehabilitation of the railway sections Serbian border - Dragoman - Sofia - Elin Pelin; Vidin Sofia, and Sofia - Pernik - Radomir - Kulata through Connecting Europe Facility, as well as through alternative financial resources. This project also covers the construction activities at the rail lines Dragoman - Sofia; Vidin - Medkovets and renewal of railway junction Sofia.

The main investment priority axis, concerning conventional railway network of the country are also indicated in the Operational Programme. They cover the construction of intermodal terminals where transshipment activities among railway, inland waterway, sea and road transport are available. In this regard, the main objective of the funding is an intermodal terminal to be constructed at railway station Ruse, which will be directly linked with the Black Sea via the railway section Ruse - Varna. Another investment project of this priority axis is the rehabilitation of key railway stations that will result in better mobility of passengers and building interconnections up the infrastructure of the underground, bus and air transport. As part of the development of the conventional rail lines along TEN-T network is also the implementation of innovative, comprehensive and interoperable railway systems for noise mitigation in the urban areas. All these activities are related to the implementation of the European Railway Traffic Management System and GSM-R along Bulgarian section of Orient-East/Med Corridor.

In Table 2 below, the allocation of the funding for investment projects in the railway transport through Operational Programme „Transport and transport infrastructure" $2014-2020$ is presented.

The main beneficiary of the aforementioned projects is National Railway Infrastructure Company. As can be seen from the table, the private sector participates in the projects with zero funding, which does not exclude the opportunities to be attracted as a partner in a public-private partnership. The program stipulates that except for Connecting Europe Facility, alternative sources of funding could be used. This means that partnerships among private initiatives and National Railway Infrastructure Company are possible in order to promote construction of core network corridors through the territory of the country. 
Table 2 Total value of the funding for investment projects in the railway transport

\begin{tabular}{|c|c|c|c|c|c|}
\hline Project & $\begin{array}{c}\text { Funding } \\
\text { by EU } \\
\text { (euros) }\end{array}$ & $\begin{array}{l}\text { Type of } \\
\text { Fund }\end{array}$ & $\begin{array}{l}\text { National } \\
\text { public } \\
\text { funding } \\
\text { (euros) }\end{array}$ & $\begin{array}{l}\text { National } \\
\text { private } \\
\text { funding } \\
\text { (euros) }\end{array}$ & $\begin{array}{l}\text { Total value } \\
\text { of the } \\
\text { funding } \\
\text { (euros) }\end{array}$ \\
\hline $\begin{array}{l}\text { Priority axis "Development of the railway } \\
\text { network along TEN-T network" - the main } \\
\text { projects are modernization of the railway line } \\
\text { Plovdiv - Burgas implementation of } \\
\text { interlocking systems in the section Karnobat } \\
\text { - Burgas; development of railway junctions } \\
\text { Plovdiv and Burgas; rehabilitation of the rail } \\
\text { line Plovdiv - Orizovo - Mihailovo; } \\
\text { rehabilitation of the section Sofia-Septemvri }\end{array}$ & 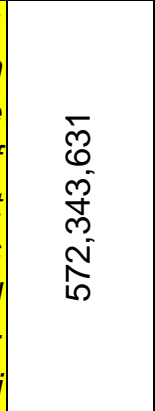 & 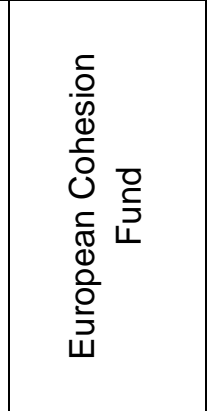 & $\begin{array}{l}\frac{\infty}{\infty} \\
\infty \\
\varnothing \\
0 \\
0\end{array}$ & 0 & 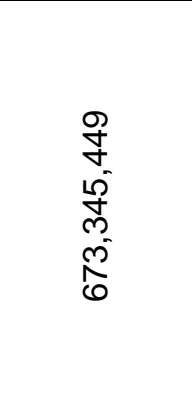 \\
\hline $\begin{array}{l}\text { Priority axis "Improvement of the mobility of } \\
\text { passengers and development of sustainable } \\
\text { public transport" - the main projects are: } \\
\text { construction of intermodal terminal in Ruse; } \\
\text { rehabilitation of key railway stations in the } \\
\text { section Ruse - Varna }\end{array}$ & $\begin{array}{l}8 \\
8 \\
8 \\
8 \\
8 \\
\text { ¿ }\end{array}$ & 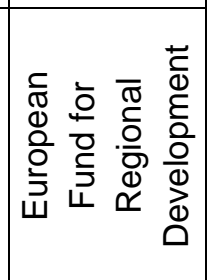 & 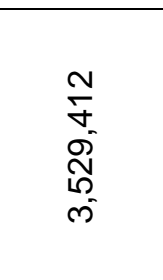 & 0 & 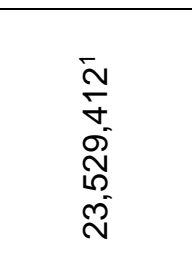 \\
\hline $\begin{array}{l}\text { Priority axis "Investments in information and } \\
\text { services management - implementation of } \\
\text { traffic management systems and } \\
\text { improvement of safety and security of the } \\
\text { transport services" - implementation of the } \\
\text { GSM - R network in the railway transport }\end{array}$ & 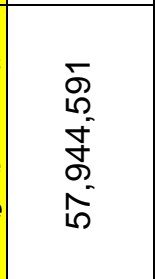 & 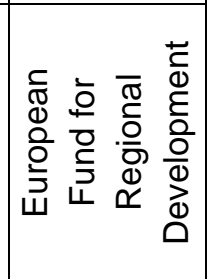 & 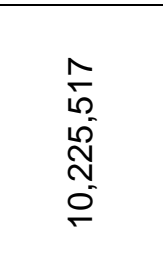 & 0 & $\begin{array}{l}\tilde{D}_{0}^{\infty} \\
0 \\
0 \\
\frac{0}{\infty} \\
0 \\
0\end{array}$ \\
\hline
\end{tabular}

Source: Operational Programme "Transport and transport infrastructure", MTITC, 2015

\section{CONCLUSIONS}

When analyzing the possibilities for stimulating public-private partnerships for investment projects in railway transport infrastructure in their preparation and realization phase, the following measures must be taken into account:

- risks, relative to the right project management and control of the activities for the construction of railway infrastructure corridors must be planned as early as possible;

- fair risk allocation between public and private partners, depending on their responsibilities for the fulfillment of the project must be made;

${ }^{1}$ Sum covers the total funding in this priority axis

${ }^{2}$ Sum covers the total funding in this priority axis
- the most appropriate and optimal form of PPP must be chosen, after taking into account the considerations of the public partner;

- Enhance the effectiveness of project control phase as a result of the strict monitoring of the obligations of both parties must be achieved.

Having in mind the fundamental principle of superiority of public partner over the private one, it is necessary variable financial schemes (e.g. a combination of private and public financial resources) for the construction of railway infrastructure to be presented. Moreover, the public-private partnerships is an opportunity that the good financial practice of the private partner could be successfully applied in the construction 
of railway infrastructure as an alternative to the road network.

Considering the main purpose of the investment projects (see Table 2) in railway transport infrastructure, as well as the opportunities to combine private financing sources with EU funds and national funding, the most appropriate type of PPP will be Design - Bid - Build. This is also determined by the fact that most of the activities to be carried out are related to modernization and rehabilitation of the railway network in order to ensure interoperability between information and communication applications of ERTMS and GSM - R. As a result, both partners (National Railway Infrastructure Company and the private company) and the society will benefit from the partnership. On one hand, the fulfillment of the projects will bring to the private company better financial results and will ensure the quality of the services provided and realization of social and economic benefits for the infrastructure users, such as reduction of noise and pollution; shortening of delivery times; higher speeds for movement of trains. On the other hand, the public partner will be exempt from the financial risk during the rehabilitation phase when the potential costs for the construction activities are relatively high, but will still remain infrastructure operator and will be eligible to collect revenues from infrastructure charges.

\section{WORKS CITED}

Bodewig, K. S. (2014). Attracting investments towards transport infrastructure - potential lines for action. Brussels: European Commission - Directorate-General for Mobility and Transport.

DGMT. (2015). TEN-T Connecting Europe. (Directorate General for Mobility and Transport) Retrieved October 31, 2015, from Mobility and Transport: http://ec.europa.eu/transport/themes/infrastructure/ten-t-guidelines/corridors/index_en.htm

DGRP, D. G. (2003). Guidelines for successful public-private partnerships. European Commission.

Directorate General for Mobility and Transport. (2015). Statistical pocketbook for 2015. European Commission. Retrieved from http://ec.europa.eu/transport/factsfundings/statistics/doc/2015/pocketbook2015.pdf

EP. (2013, December 20). Regulation 1315/2013 of the European Parliament and of the Council on Union guidelines for the development of the trans-European transport network. Retrieved from EUR-Lex: http://eur-lex.europa.eu/legal-content/EN/TXT/?uri=celex:32013R1315

EP. (2013, December 20). Regulation 1316/2013 on the European Parliament and of the Council on establishing the Connecting Europe Facility. European Parliament. Brussels, Belgium.

Gechev et al, R. (2015, Dec 11). Politiki i instrumenti za stimulirane na investitsionniya protses v stranata na osnovata na publichno-chastnoto partn'orstvo. Retrieved Apr 22, 2016, from http://www.unwe.bg/bg/news/8409/-

\%D0\%BF\%D0\%BE\%D0\%BB\%D0\%B8\%D1\%82\%D0\%B8\%D0\%BA\%D0\%B8-\%D0\%B8\%D0\%B8\%D0\%BD\%D1\%81\%D1\%82\%D1\%80\%D1\%83\%D0\%BC\%D0\%B5\%D0\%BD\%D1\% $82 \% \mathrm{D} 0 \% \mathrm{~B} 8-\% \mathrm{D0} \% \mathrm{~B} 7 \% \mathrm{D0} \% \mathrm{~B} 0-$

\%D1\%81\%D1\%82\%D0\%B8\%D0\%BC\%D1\%83\%D0\%BB\%D0\%B8\%D1\%80\%D0\%B0\%D0\% BD\%D0\%B5-\%D0\%BD\%D0\%B0-\%D0\%B8

MTITC. (2014). Operational Programme "Transport and transport infrastructure 2014 - 2020". Sofia: Ministry of Transport, Information Technologies, and Communications.

MTITC, M. o. (2014). Operational Programme "Transport and Transport Infrastructure". Sofia.

Received for publication: 30.03 .2017

Revision received: $\quad 20.04 .2017$

Accepted for publication: 01.05.2017 


\section{How to cite this article?}

Style - APA Sixth Edition:

Koralova, P. (2017, July 15). Construction of railway transport corridors in Bulgaria by promoting publicprivate partnership. (Z. Čekerevac, Ed.) MEST Journal, 5(2), 78-86. doi:10.12709/mest.05.05.02.08

Style - Chicago Sixteenth Edition:

Koralova, Petya. "Construction of railway transport corridors in Bulgaria by promoting public-private partnership." Edited by Zoran Čekerevac. MEST Journal (MESTE) 5, no. 2 (July 2017): 78-86.

Style - GOST Name Sort:

Koralova Petya Construction of railway transport corridors in Bulgaria by promoting public-private partnership [Journal] // MEST Journal / ed. Čekerevac Zoran. - Toronto - Belgrade : MESTE, July 15, 2017. - 2 : Vol. 5. - pp. 78-86.

Style - Harvard Anglia:

Koralova, P., 2017. Construction of railway transport corridors in Bulgaria by promoting public-private partnership. MEST Journal, 15 July, 5(2), pp. 78-86.

Style - ISO 690 Numerical Reference:

Construction of railway transport corridors in Bulgaria by promoting public-private partnership. Koralova, Petya. [ed.] Zoran Čekerevac. 2, Toronto - Belgrade : MESTE, July 15, 2017, MEST Journal, Vol. 5, pp. 78-86. 